\title{
ПУЛЬСАЦИИ СИЛЫ ТЯЖЕСТИ И СЕЙСМИЧЕСКОГО ШУМА НА ЕВРАЗИЙСКОМ КОНТИНЕНТЕ
}

\author{
Ю. В. Антонов \\ Воронежский государственный университет \\ Дата поступления 15 сентября 2018 г.
}

\begin{abstract}
Аннотация: впервые пульсации силы тяжести были обнаружены при обработке стационарных наблюдений на Геодинамическом полигоне РАН в г. Бишкеке (2014 г.). Позже аналогичные пульсаиии были выявлены в сейсмических стационарных наблюдениях в г. Воронеже (Геофизическая служба РФ, 2015 г.), которые синхронно совпадали с гравиметрическими пульсациями в г. Бишкеке. Указанное обстоятельство синхронности теперь проанализировано для других регионов России, где имеются данные по сейсмическим и гравиметрическим наблюдениям. В частности рассмотрены примеры синхронных вариаций вертикальной составляющей сейсмического и гравитационного полей на станциях Арти (Россия, Екатеринбург), Воронеж (Россия), м. Шульи (Россия, Приморье) и в г. Бишкек (Кыргызстан). Пульсаиии неприливных вариаций силы тяжести и сейсмического поля в указанных пунктах существуют синхронно. Частотные характеристики также тождественны. Скорее всего, пульсаиии обусловлены метеорными потоками. Наибольшая плотность метеорных потоков приурочена к зимним месяиам. Пульсации имеют периоды колебаний в пределах 0-20 мин.
\end{abstract}

Ключевые слова: пульсаиии; вертикальная составляющая сейсмического поля; лунно-солнечные вариации силы тяжести; неприливные вариации силь тяжести; корональные выбросы масс; метеорные потоки; сейсмический шум.

\section{GRAVITY AND SEISMIC NOISE PULSATIONS ON THE EURASIAN CONTINENT}

\begin{abstract}
First time, gravity pulsations were detected during processing of stationary observations at the Geodynamic range of RAS in Bishkek (2014). Later similar pulsations were revealed in seismic stationary observations in Voronezh (Geophysical service of the Russian Federation, 2015), which coincided with gravimetric pulsations in Bishkek. The mentioned synchronicity circumstance is now analyzed for other regions of Russia where data on seismic and gravimetric observations are available. In particular, the examples of synchronous variations of the vertical component of seismic and gravitational fields at the stations of Arti (Russia, Yekaterinburg), Voronezh (Russia), M. Schultz (Russia, Primorye) and Bishkek (Kyrgyzstan) are considered. Ripples of non-tidal variations of gravity and seismic field in these points exist synchronously. The frequency characteristics are also identical. Most likely, the ripples are due to meteor showers. The greatest density of meteor showers is confined to the winter months. Pulsations have periods of oscillation in the range of $0-20 \mathrm{~min}$.
\end{abstract}

Keywords: vertical component of the seismic field the seismic noise; lunar-solar variations in gravity; non-tidal variations of gravity; coronal mass; meteor showers; ripple.

\section{Введение}

Впервые неприливные пульсации силы тяжести были обнаружены при обработке стационарных гравиметрических наблюдений на Геодинамическом полигоне РАН в г. Бишкеке (2014 г.). Получены они (пульсации) были путем исключения из гравиметрических наблюдений лунно-солнечных вариаций силы тяжести и смещения нуль-пункта $[1,2]$. Проявляются пульсации в виде увеличения амплитуды колебаний гравитационного поля продолжительностью от нескольких часов до нескольких суток.

Позже аналогичные пульсации были выявлены в сейсмических стационарных наблюдениях [3] в г. Воронеже (Геофизическая служба РФ, 2015 г.), которые синхронно совпадали с гравиметрическими пульсациями в г. Бишкеке. Это совпадение не случайное. Дело в том, что для измерений гравитационного и сейсмического полей служит один и тот же датчик - верти- 
кальный сейсмограф Голицына, о чем подробно изложено в [4].

При исследовании переменного гравитационного поля, прежде всего, обращают внимание на лунносолнечные вариации силы тяжести, которые образуют волнообразный пакет колебаний. Кроме лунносолнечных вариаций силы тяжести существуют другие гравитационные колебания различной амплитуды и периодов, которые (колебания) образуются в недрах Земли, ближнем и дальнем космосе. Одним из таких проявлений могут служить пульсации гравитационного поля, выявленные автором [1-3] при анализе неприливных аномалий силы тяжести. Попытаемся объяснить природу выявленных пульсаций силы тяжести.

\section{Исходные данные для анализа неприливных вариаций}

Исходным материалом для данной статьи послужили мониторинговые наблюдения силы тяжести на Геодинамическом полигоне РАН в г. Бишкек (Киргизстан) с помощью гравиметра SG - 5 Autograv. Прибор установлен в штольне с постоянной температурой около $8^{\circ}$ примерно в 30 км от города, так что помехи техногенного характера практически отсутствуют. Привлечены мониторинговые измерения силы тяжести во Владивостоке (м. Шульц) и со станции Арти (г. Екатеринбург), где используются приливные гравиметры gPhone (Micro - g - LaCoste). Гравиметрический пункт м. Шульц расположен в зоне перехода от азиатского континента к Тихому океану, на территории Морской экспериментальной станции Тихоокеанского океанологического института ДВО РАН (мыс Шульца, залив Петра Великого, Японское море). Пункт Арти расположен в центре Евразийского континента (Урал, г. Екатеринбург). Использованы также сейсмические наблюдения в Воронеже (пункты Сторожевое и Галичья Гора ГС РАН в ЦентральноЧерноземном районе). Указанные пункты расположены в центре Русской платформы, где практически отсутствуют помехи, присущие тектонически-активным регионам (гг. Бишкек и Владивосток). Для сравнения в Воронеже выбраны только сейсмические данные из-за того, что мониторинговых гравиметрических данных в Воронеже нет [3]. Автор благодарит за предоставленные сейсмические и гравиметрические материалы Л. И. Надежку (ВГУ), М. Г. Валитова (ТИО ДВО РАН), А. К. Рыбина (ГП РАН) и А. С. Бебнева (Институт геофизики УрО РАН).

\section{Методика обработки и интерпретации неприливных вариаций силы тяжести}

Наблюденные значения силы тяжести представляют собой лунно-солнечные вариации, осложненные региональным фоном (чаще линейным). Региональный фон обусловлен смещением нуль-пункта прибоpa, а также влиянием внешних факторов [2]. Чтобы получить неприливную вариацию силы тяжести необходимо удалить лунно-солнечные вариации и фон. После соответствующей обработки [2, 3] наблюден- ных вариаций силы тяжести получена так называемая неприливная вариация силы тяжести. Неприливные вариации (рис. 1a) представляют собой кривую высокочастотных колебаний, которые в свою очередь модулируются более длиннопериодными колебаниями.

Для вычисления пульсаций в данном конкретном случае использовалось осреднение. Отмети также, что при использовании метода осреднения появляется возможность вычисления пульсаций без промежуточных операций по учету лунно-солнечных вариаций и нуль-пункта. Поскольку пульсации силы тяжести имеют те же периоды, что и остаточные неприливные вариации $[1,2]$, то можем использовать метод скользящего окна 10 мин. Наиболее оптимальный вариант осреднения с интервалом 5-10 мин., что легко выявить на расчетных лунно-солнечных вариациях. Добавим, что вычисление остаточных неприливных вариаций можно сделать с помощью сплайн сглаживания, на что указывалось в [1-3].

Методика выделения пульсаций важна еще тем, что
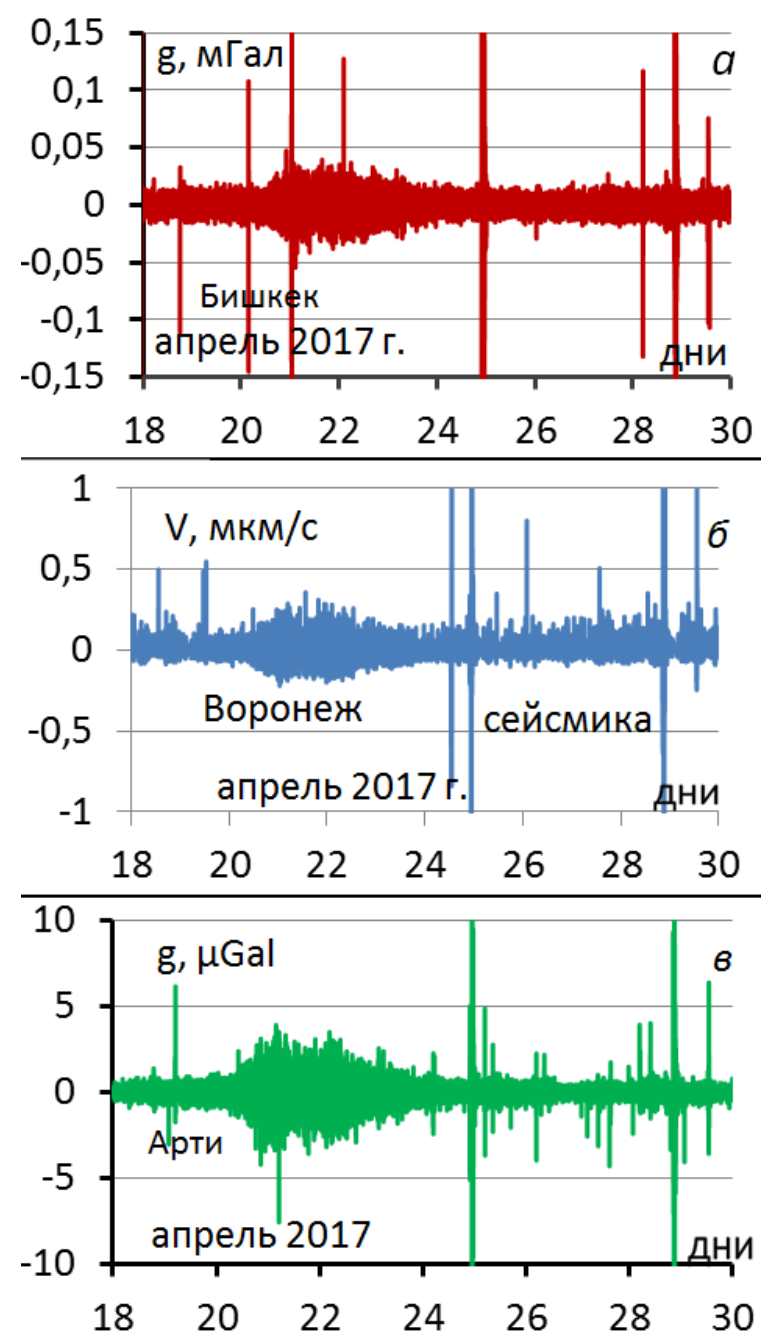

Puc. 1. Пульсации гравитационного и сейсмического полей в апреле 2017 г.: $a$ - пульсация силы тяжести в Бишкеке; $\sigma$ - сейсмическая пульсация в г. Воронеже (ст. Галичья Гоpa); в - пульсация силы тяжести в Арти. 
она может быть использована при выделении «сейсмических бурь» $[5,6]$. Земля создает постоянные сейсмические колебания, которые регистрируются непрерывно сейсмографом и называются сейсмическим шумом. Амплитуда этих колебаний очень мала, но в отдельные моменты амплитуда их вдруг увеличивается на несколько порядков. Такие увеличения амплитуд шумов называют «сейсмическими бурями». Сейсмические бури могут длиться несколько дней и хорошо идентифицируются [7, 8]. Далее по тексту «сейсмические бури» по аналогии с пульсациями силы тяжести будем называть также пульсациями

\section{Обсуждение результатов}

Рассмотрим конкретно сейсмические и гравитационные неприливные вариации, происшедшие в апреле 2017 г. в Бишкеке, Воронеже и Арти (рис. 1). Во всех указанных пунктах четко выделяются пульсации, которые полностью совпадают между собой. Пульсации начинаются с резкого увеличения амплитуды колебаний, которые затем медленно уменьшаются в течение более двух суток. Пульсации вызваны метеорным потоком Лириды, которые стабильно появляются в период с 24 по 24 апреля. Для данного отрезка времени характерно большое количество землетрясений. К окончанию пульсации приурочено мощное землетрясение 25 апреля 2017 г. у побережья Чили (магнитуда M=7,2). Остальные землетрясения имеют магнитуды не более 5 единиц и связаны с сопредельными территориями (Алтай, Афганистан и Киргизстан).

На рис. 2 представлены пульсации в тех же пунктах за то же самое время в 2015 г. Пульсации в 2015 г. начинаются на сутки позже чем в 2017 г. Это расхождение можно объяснить тем, что в нашем случае время фиксируется по григорианскому календарю, а не по юлианским дням, как это принято в астрономии. Это расхождение может быть связано также с изменением плотности метеорного потока или с изменением орбиты потока. К завершению пульсации, как и в 2017 г., приурочено катастрофическое Непальское землетрясение $(\mathrm{M}=7,8)$, которое произошло 25 апреля с повторением через сутки с такой же магнитудой. В наблюдениях 2015 года есть одно существенное отличие: рядом с пульсацией в период 22-25 апреля отмечается еще одна подобная пульсация 26-29 апреля, которой нет в 2017 г. Если присмотреться внимательно к наблюдениям 2017 г., то очень слабые пульсации силы тяжести все-таки имеют место быть. Объяснить такое различие можно тем, что пульсации определяются метеорными потоками Виргиниды и Альфа Боотиды, которые не всегда проявляются в измерениях. Причины указаны выше: плотность метеорного потока или отклонением самой орбиты при встрече с Землей. Кроме того, как было установлено ранее [5], пульсации могут возникать из-за прохождения атмосферных фронтов.

В данной статье специально рассматриваются результаты измерений за 2015 и 2017 гг. В эти годы космическая погода резко отличалась. 2017 год харак- теризуется исключительно низкой активностью, что обусловлено годом спокойного Солнца. В 2015 г. и первая половина 2016 г. космическая погода выдались крайне возбужденной [9]. В качестве примера приведены данные неприливных вариаций за вторую половину октября 2017 г. (рис. 3). Остаточные аномалии сейсмического и гравитационного поле меняются незначительно, может быть, за исключением пульсации небольшой амплитуды, возникшей 18 октября. Несколько «изрезанными» выглядят сейсмические пульсации в Воронеже (ст. Сторожевое), что связано с техногенными помехами.
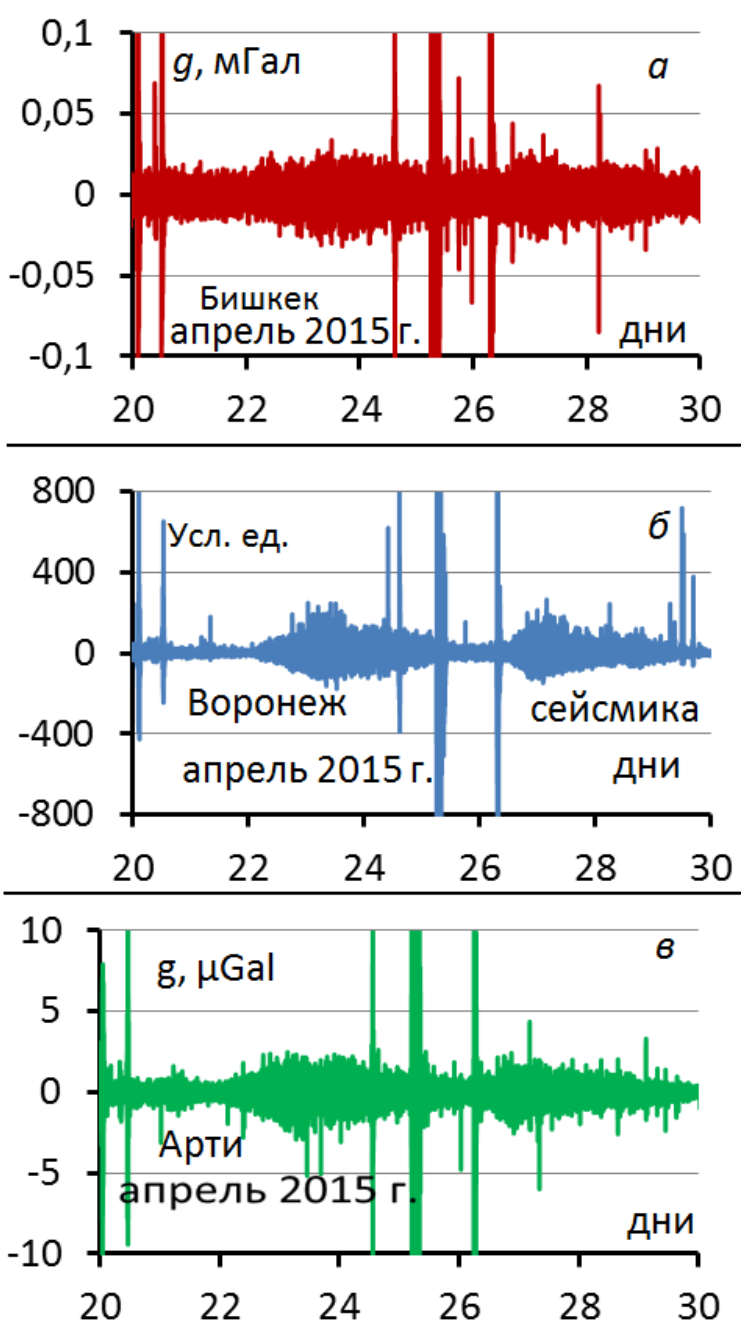

Puc. 2. Пульсации гравитационного и сейсмического полей в апреле 2015 г.: $a$ - пульсация силы тяжести в Бишкеке; $\sigma$ - сейсмическая пульсация в г. Воронеже (ст. Сторожевое); в - пульсация силы тяжести в Арти.

А вот неприливные вариации в те же числа 2015 г. (рис. 4) имеют очень резкую изменчивость. Амплитуды изменения гравитационного и сейсмического полей в десятки и в сотни раз превышают погрешности измерений. Обращает на себя внимание, например, всплеск неприливной вариации силы тяжести в Бишкеке (рис. 4, a), амплитуда которой достигает 0,2 мГал, что по величине сравнимо с лунно-солнечными 


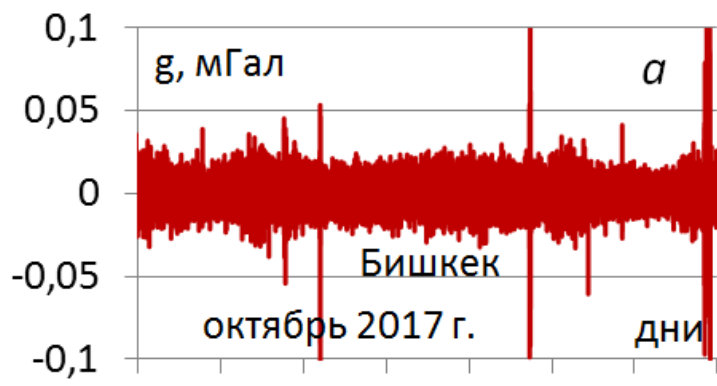

$\begin{array}{llllllll}15 & 17 & 19 & 21 & 23 & 25 & 27 & 29\end{array}$

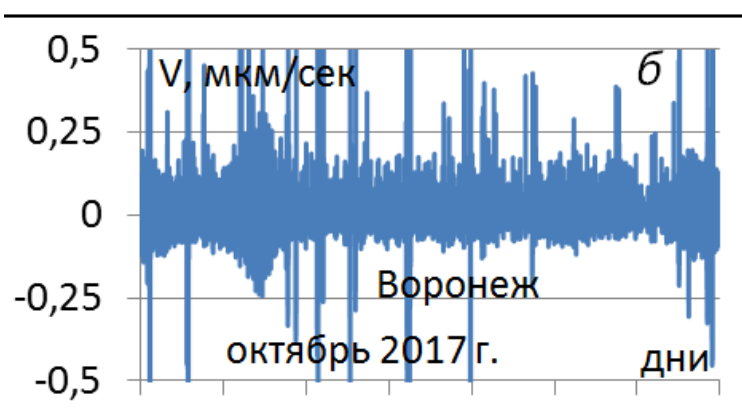

$\begin{array}{llllllll}15 & 17 & 19 & 21 & 23 & 25 & 27 & 29\end{array}$

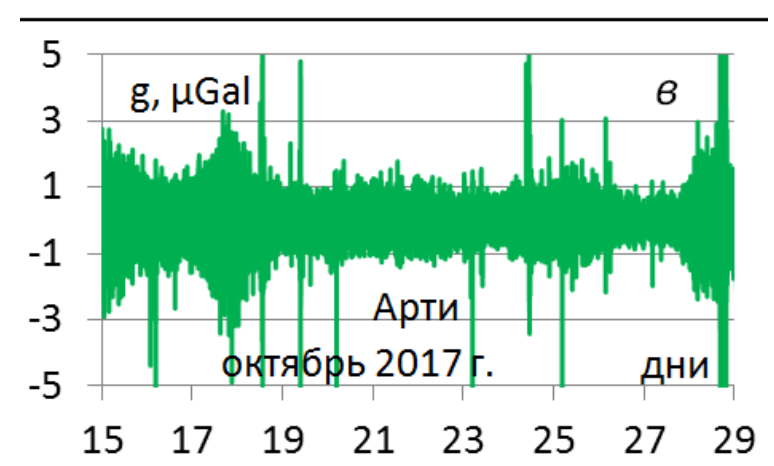

Puc. 3. Пульсации гравитационного и сейсмического полей в октябре 2017 г.: $a$ - пульсация силы тяжести в Бишкеке; $\sigma$ - сейсмическая пульсация в г. Воронеже (ст. Сторожевое); в - пульсация силы тяжести в Арти.

вариациями. Под стать изменяются пульсации сейсмического поля в Воронеже. Обусловлены такие всплески поведением потока заряженных частиц в основном от Солнца [10]. Следует обратить внимание на уменьшение амплитуды всплеска в Арти. Дело в том, что в Бишкеке используется для измерения гравиметр CG - 5 Autograv с емкостным датчиком, а в Арти - gPhone (Micro - g - LaCoste) со стрелочным компенсатором. Отсюда следует вывод о преимуществе измерений силы тяжести приливных гравиметров.

Рассмотрим еще пульсации силы тяжести и сейсмического поля в четырех пунктах (Воронеж, Арти, Бишкек, Владивосток), охватывающих по долготе почти весь Евразийский континент, для февраля месяца в 2015 г. (рис. 5-8). К сожалению, данных по пульсациям в 2017 г. для Владивостока не имеется. Для февраля месяца характерны стабильные не только резкие изменения погоды, но и пульсаций. Гравиметрические пульсации (рис. 5) в первой половине фев-

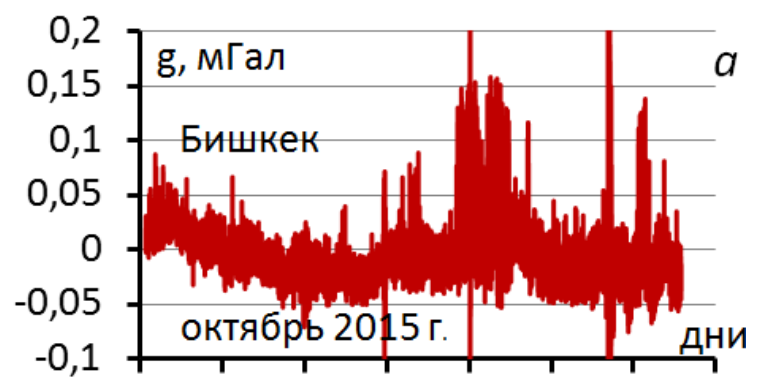

$\begin{array}{llllllll}15 & 17 & 19 & 21 & 23 & 25 & 27 & 29\end{array}$
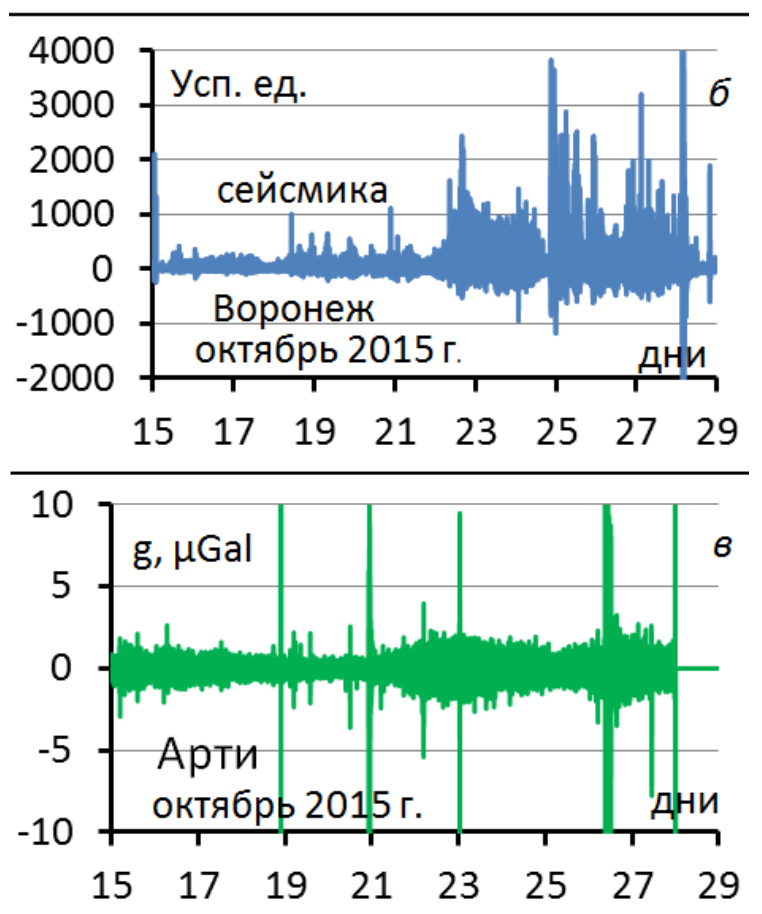

Puc. 4. Пульсации гравитационного и сейсмического полей в октябре 2015 г.: $a$ - пульсация силы тяжести в Бишкеке; $\sigma$ - сейсмическая пульсация в г. Воронеже (ст. Сторожевое); в - пульсация силы тяжести в Арти.

раля во всех перечисленных пунктах практически полностью совпадают. Несколько более изрезаны пульсации во Владивостоке (рис. 5,б), так как гравиметр находится на мысе Шульца на берегу моря, где ощущается сильное влияние морских волн. Пульсации сейсмического поля (рис. 6) в Воронеже и во Владивостоке тоже совпадают между собой и с пульсациями силы тяжести (рис. 5). Время сейсмических и гравиметрических пульсаций совпадает с метеорными потоками Центавриды: 8 февраля - Альфа, 12 февраля - Омикрон, и 16 февраля - Тета Центавриды.

Несколько иначе выглядят пульсации силы тяжести в конце января 2015 г. Как правило, к отрезку времени 27-31 января приурочен метеорный поток Альфа Кариниды. В Бишкеке и Арти пульсации совпадают между собой (рис. 7, $а$, б), а вот на мысе Шульца (рис. 7, а) видим существенное отличие. Причиной отличия пульсации являются атмосферные процессы, происходящие на берегу океана. Отметим любопытную деталь в пульсации на рис.7. В течение 

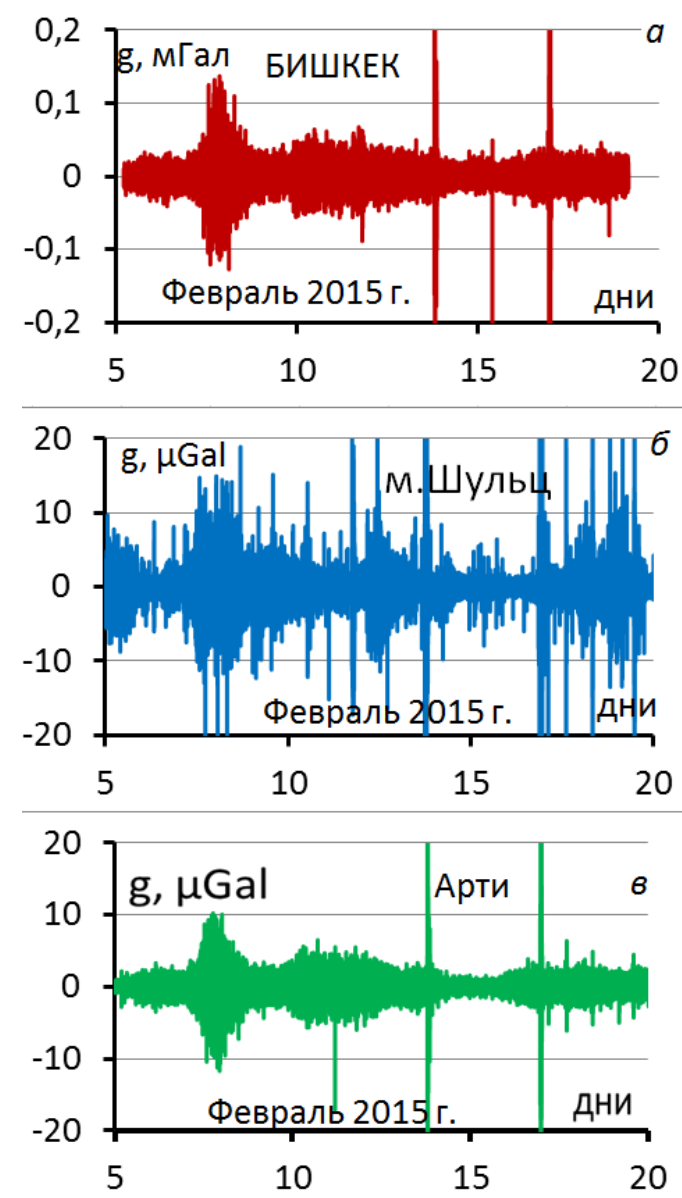

Puc. 5. Сравнение пульсаций силы тяжести в Бишкеке, Владивостоке и Арти в феврале 2015 г.: $a$ - пульсации силы тяжести в Бишкеке ; $\sigma$ - пульсации силы тяжести во Владивостоке; 8 - пульсации силы тяжести в Арти.
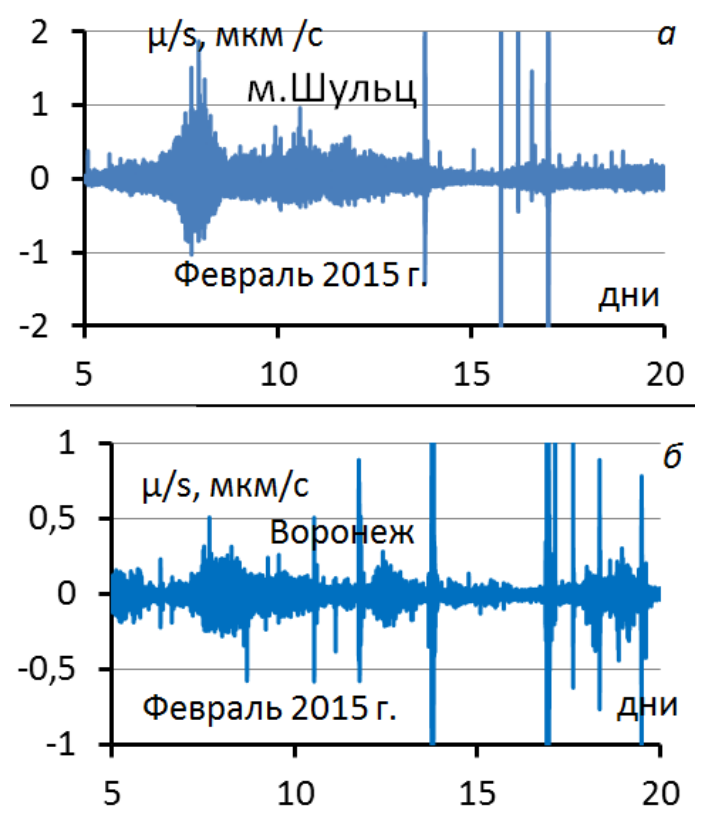

Puc. 6. Сравнение пульсаций сейсмического поля во Владивостоке и Воронеже в феврале 2015 г.: $a$ - пульсации силы тяжести во Владивостоке; $a$ - данные акселерометра во Владивостоке; $\sigma$ - пульсации сейсмического поля в Воронеже.
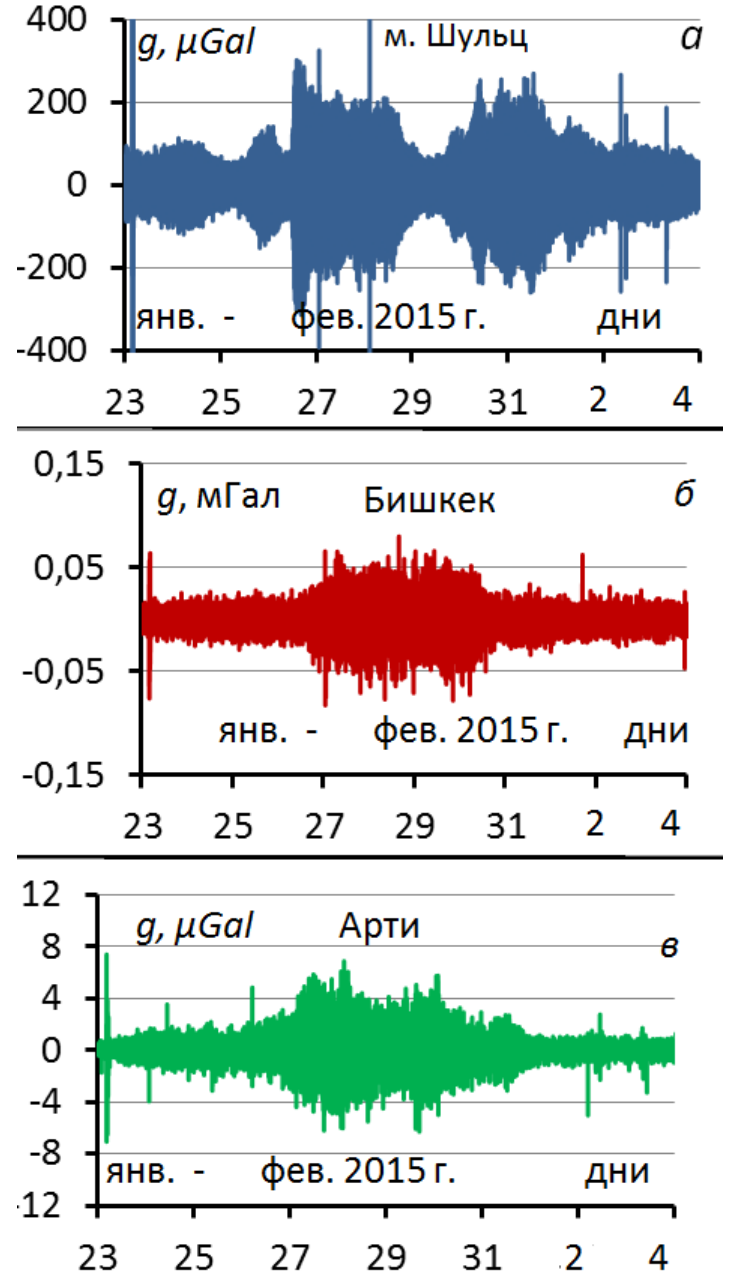

Puc. 7. Сравнение пульсаций силы тяжести в Бишкеке, Владивостоке, и Арти в феврале 2015 г.: $a$ - пульсации силы тяжести в Бишкеке ; $\sigma$ - пульсации силы тяжести во Владивостоке; 8 - пульсации силы тяжести в Арти.

недели на мысе Шульца стояла пасмурная погода с северным ветром при скорости 10 м/сек, а 29 января всего на одни сутки установилась штилевая погода (2 м/сек) с переходом ветра с северного на восточное направление. К этому времени приурочена нулевая пульсация, что собственно лишний раз подтверждает влияние атмосферных процессов на показания гравиметров и сейсмографов [5].Та же картина наблюдается при сравнении данных акселерометра в Приморье (рис. 7, а) и сейсмографа в Воронеже (рис. 7, б).

В связи с рассмотренным материалом в статье следует еще раз повторить выводы сделанные автором ранее в [1-8]: в пульсациях гравитационного и сейсмического полей проявляется четкая сезонность. Но Земля пересекает метеорные потоки в течение всего года, так почему же тогда пульсации проявляются в основном в осенне-зимний период. В весеннелетний период наблюдаются наиболее яркие метеорные дожди. Дело в том, что мощность (плотность) метеорного потока в астрономии, так сложилось исторически, оценивается зенитным часовым числом - количеством наблюдаемых метеоров за час. Наблюдаемые 

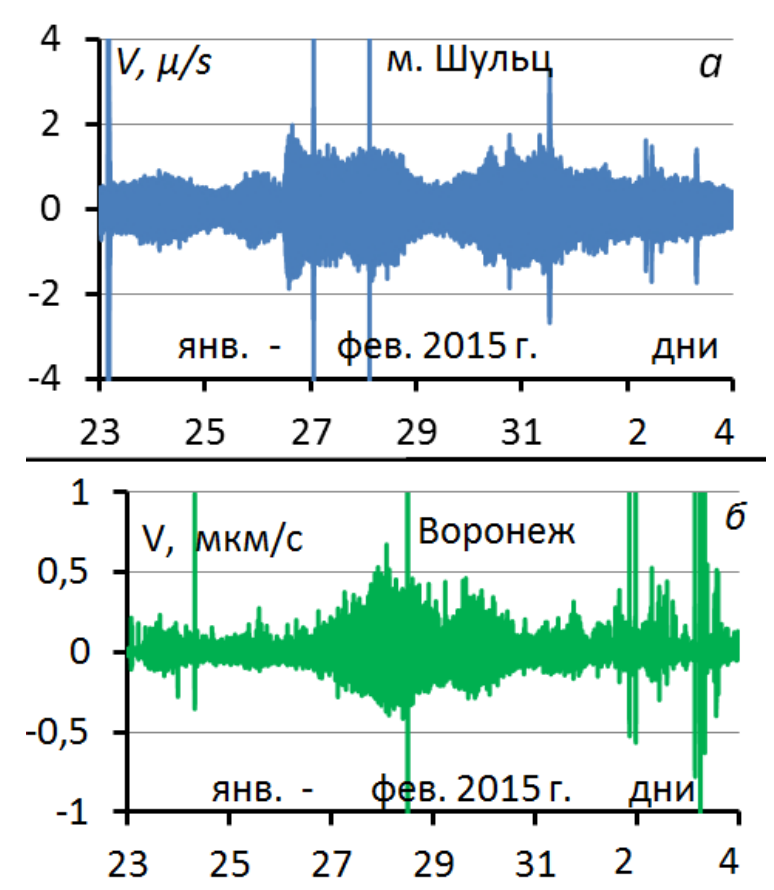

Рис. 8. Сравнение пульсаций сейсмического поля во Владивостоке и Воронеже в январе- феврале 2015 г.: $a$ данные акселерометра во Владивостоке; $\sigma$ - пульсации сейсмического поля в Воронеже.

метеоры создаются наиболее крупными частицами, а плотность метеорного потока чаще определяется мелкими частицами. В качестве примера можно привести наиболее зрелищный метеорный поток Персеиды (середина августа месяца), который практически не вызывает пульсаций (их может заметить очень опытный наблюдатель), а вот потоку Центаврид (февраль месяц), у которого зенитное число на два порядка меньше, чем у Персеид в августе, соответствуют интенсивные и длительные пульсации.

\section{Заключение}

Связь между пульсациями гравитационного и сейсмического полей однозначна. Судя по расположению пунктов мониторинга на Евразийском континенте (от Воронежа до Владивостока), эта связь носит глобальный характер. Высказанные предположения о физи- ческой природе пульсаций, возможно, в дальнейшем позволят использовать их для глубинного изучения Земли, а также для изучения метеорных потоков. В прикладном плане изучение пульсаций внесет определенные коррективы в методику высокоточных измерений силы тяжести. Измерения силы тяжести, выполненные в дни гравиметрических (по аналогии с магнитными) «бурь», которые произошли в январе феврале 2015 г. (рис. 5-8) лучше исключить. А лучше всего в эти дни не проводить измерений, так как дни появления гравиметрических пульсаций известны и повторяются они из года в год.

\section{ЛИТЕРАТУРА}

1. Антонов, Ю. В. Пульсации неприливных вариаций силы тяжести / Ю. В. Антонов // Изв. ВУЗов. Геол. и разведка. 2014. - № 5. - С. 54-57.

2. Антонов, Ю. В. Разделение неприливных вариаций силы тяжести на основе спектрального анализа и метода осреднения/ Ю. В. Антонов // Вестн. Воронеж. гос. ун-та. Сер.: Геология. - 2016. - № 2. - С. 100-106.

3. Антонов, Ю. В. Синхронные пульсации в неприливных вариациях гравитационного и сейсмического полей / Ю. В. Антонов, И. А. Сизаск // Геология и разведка. Изв. ВУЗ. 2015. - №5. - C. 46-52.

4. Антонов, Ю. В. Сравнение приливных вариаций силы тяжести и вертикальной составляющей сейсмографа/ Ю. В. Антонов, И. Ю. Антонова // Геофизика. - 2013. - №2. - С. $27-31$.

5. Антонов, Ю. В. Влияние атмосферного фронта на показания гравиметров и сейсмометров / Ю. В. Антонов // Геология и разведка. Изв. ВУЗ. - 2017. - №4. - С. 66-71.

6. Рыкунов, Л. Н. Микросейсмы / Л. Н. Рыкунов // М.: Наука, 1967. - $86 \mathrm{c}$.

7. Антонов, Ю. В. Возможная природа пульсаций неприливных вариаций силы тяжести/ Ю. В. Антонов // Экологический вестник научных центров ЧЭС. - 2015. - №4. - С. 5-13.

8. Антонов, Ю. В. Природа неприливных вариаций силы тяжести / Ю. В. Антонов // Вестн. Воронеж. гос. ун-та. Сер.: Геология. - 2017. - № 3. - С. 100 - 106.

9. Антонов, Ю. В. Аномальное поведение неприливных вариаций силы тяжести / Ю. В. Антонов // Геология и разведка. Изв. ВУЗ. - 2016. - №2. С. - 70-76.

10. Антонов, Ю.В. . Всплески неприливных вариаций силы тяжести / Ю.В. Антонов // Геофизика. - 2017. - №1. C. 28-34.

\section{Voronezh State University}

Antonov Yu. V., professor Geophysical Department

E-mail:yuriyantonov@yandex.ru

Tel.: (473) 2208385 